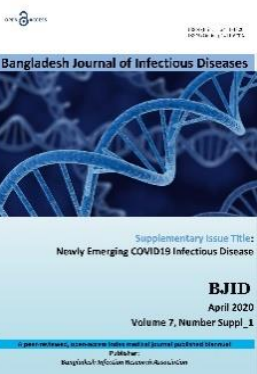

\title{
Routes of Transmission of Newly Emerging SARS-CoV-2: A Systematic Review
}

\author{
Mahmuda Yeasmin ${ }^{1}$, Jannatut Tasnim ${ }^{2}$, Arifa Akram $^{3}$, Md. Abdullah Yusuf ${ }^{4}$, \\ AKM Shamsuzzaman ${ }^{5}$, Md. Maruf Ahmed Molla ${ }^{6}$, Asish Kumar Ghosh ${ }^{7}$
}

\begin{abstract}
${ }^{1}$ Medical Officer, Department of Virology, National Institute of Laboratory Medicine \& Referral Centre, Dhaka, Bangladesh; ${ }^{2}$ Lecturer, Department of Biochemistry, Popular Medical College, Dhaka, Bangladesh; ${ }^{3}$ Assistant Professor, Department of Virology, National Institute of Laboratory Medicine and Referral Center, Dhaka, Bangladesh; ${ }^{4}$ Assistant Professor, Department of Microbiology, National Institute of Neurosciences \& Hospital, Dhaka, Bangladesh; ${ }^{5}$ Director \& Professor of Microbiology, National Institute of Laboratory Medicine and Referral Center, Dhaka, Bangladesh; ${ }^{6}$ Medical Officer, Department of Virology, National Institute of Laboratory Medicine \& Referral Centre, Dhaka, Bangladesh; ${ }^{7}$ Graduate in MD virology, Officer on Special Duty, Director General Health Services and Ministry of Health and Family Welfare, Dhaka, Bangladesh
\end{abstract}

[Received: 6 April 2020; Accepted: 12 April 2020; Published: 25 April 2020]

\begin{abstract}
Background: In December 2019, a novel corona virus (SARS-CoV-2) causes atypical pneumonia now known as "corona virus disease 2019" (COVID-19) emerged in Wuhan, China and spread rapidly throughout the world. Objective: The purpose of the present study was to identify the different plausible routes of transmission of SARS-CoV-2 into the human body. Methodology: We searched electronic databases (MEDLINE, EMBASE, Science Citation Index, WHO reports and news) checked documents and references. We included all the studies regarding potential routes of transmission of SARS-CoV-2. All reviewers independently screened titles and abstracts, assessed studies for inclusion, appraised quality, and extracted data. Result: SARS-CoV-2 has been found to have higher level of transmissibility than other two pathogenic CoVs. Sustained human to human transmission of SARS-CoV-2 has already been established though the exact route of transmission is yet to be determined. Similar to other CoVs, respiratory droplet and contact with contaminated surfaces are considered as principle route of transmission of SARS-CoV-2 whereas aerosol, feco-oral, perinatal, ocular surface and transfusion transmissions are the plausible route of spreading of this highly pathogenic CoVs. Conclusion: In the current review, we summarize the potential route of transmission of SARS-CoV-2 in the light of previous SARS-CoV and MERS-CoV outbreaks to solidify the scientific basis on which important decisions can be made. [Bangladesh Journal of Infectious Diseases, April 2020;7(suppl_1):S18-S31]
\end{abstract}

Keywords: Routes of transmission; newly emerging; SARS-CoV-2; systematic review

Correspondence: Dr. Arifa Akram, Assistant Professor, Department of Virology, National Institute of Laboratory Medicine and Referral center, Dhaka, Bangladesh; Cell no.: +8801816296249; Email: drbarna43@gmail.com

Conflict of interest: All authors have no competing interests.

Funding agency: Authors received no financial support for research or publication of this article yet.

Contribution to authors: All authors have contributed equally in literature search, analysis and writing as well as revision of the manuscript

How to cite this article: Yeasmin M, Tasnim J, Akram A, Yusuf MA, Shamsuzzaman AKM, Molla MMA, Ghosh AK. Routes of Transmission of Newly Emerging SARS-CoV-2: A Systematic Review. Bangladesh J Infect Dis 2020;7(suppl_1):S18-S31

Copyright: (92020. Yeasmin et al. Published by Bangladesh Journal of Infectious Diseases. This article is published under the Creative Commons CC BY-NC License (https://creativecommons.org/licenses/by-nc/4.0/). This license permits use, distribution and reproduction in any medium, provided the original work is properly cited, and is not used for commercial purposes. 


\section{Introduction}

The recent emergence of a novel coronavirus of zoonotic origin in Wuhan, Hubei province, China, in December 2019, has been posing widespread fear and significant threat to global health security due to its rapid national and international spread $^{1}$. The virus was officially designated as SARS-CoronaVirus-2 (SARS-CoV-2), causing severe respiratory tract infections in humans, leading to a condition that has been entitled as "coronavirus disease 2019" (COVID-19)2. As of April 2, 2020, a total of 9,40,622 cases of COVID-19 have been confirmed by nucleic acid testing of respiratory tract samples and it has caused 47,516 deaths worldwide ${ }^{3}$. WHO declared this ongoing outbreak as "Pandemic" on 11 March $2020^{4}$. Besides, current outbreak of SARSCoV-2, the world has experienced the devastating effect of another two outbreaks caused by two potentially dangerous zoonotic corona viruses in the past two decades. The first coronavirus outbreak was caused by Severe Acute Respiratory Syndrome coronavirus (SARS$\mathrm{CoV}$ ) in $2002-2003^{5}$ and second outbreak was caused by Middle East Respiratory Syndrome coronavirus (MERS$\mathrm{CoV}$ ) in $2012^{6}$.

Corona viruses were discovered in 1960s, belonging to the family Coronaviridae, within the order Nidovirales that are widely detected in mammals and birds. Coronaviridae family consisted of two subfamiliesOrthocoronavirinae and Torovirinae. There are four genera: alpha-, beta-, gamma- and delta-coronavirus, included in Orthocoronavirinae subfamily ${ }^{7}$. Including SARS-CoV-2, seven human coronaviruses have been identified so far. Among them 229E, OC43, NL63, and HKU1 cause common cold symptoms in immunocompetent individuals ${ }^{8}$ and two other SARS$\mathrm{CoV}$ and MERS-CoV are zoonotic in origin and lead to severe and potentially fatal infection ${ }^{9}$ Before emergence of SARS-CoV in 2002, coronavirus did not get so much attention as it causes mild symptoms in most of the cases ${ }^{10}$. First epidemic of $21^{\text {st }}$ century by SARSCoV in 2002, major outbreak of MERS-CoV in 2012 and another ongoing pandemic by SARS-CoV-2 have revolutionized the epidemiological concept of coronavirus $^{11}$.

Like other respiratory viruses' corona viruses transmitted from person to person by respiratory droplets. SARS$\mathrm{CoV}$ and MERS-CoV also have the potential to be transmitted by contaminated fomites and droplet nuclei or aerosol ${ }^{12}$. SARS-CoV-2 has some similarities with SARS-CoV but it is spreading faster, assuming that it is more contagious than SARS-CoV ${ }^{13}$. Person to person transmission of SARS-CoV-2 in hospital and family settings has been documented albeit the route of transmission is not clearly defined so far ${ }^{14,15,16}$. As number of cases of ongoing pandemic of COVID-19 is going rapidly and death toll breaking the previous days records every day, it is high time for strategic preparedness to mitigate the adverse effect of COVID-19 and to contain the SARS-CoV-2 in countries where its infection rate is still within limits. The COVID-19 pandemic could have infected $90 \%$ of the world population and killed 40.6 million people if no mitigation measures are taken right now to combat. Only by taking protective measures early to prevent spreading when the case fatality rate of an individual's country is 0.2 per 100,000 people per week may cut worldwide death to 1.9 million ${ }^{17}$.

Hence, sound knowledge regarding spatio-temporal transmission patterns of SARS-CoV-2 is thought to be central in developing strategies to control them, especially when its biological information is limited and no vaccine and treatment options are available. In the current review, we summarize the potential route of transmission of SARS-CoV-2 in the light of previous SARS-CoV and MERS-CoV outbreaks.

\section{Methodology}

\section{Types of studies included}

We included any study related to different routes of transmission of SARS-CoV-2 virus in a populationbased or hospital-based sample. For pragmatic reasons, we also included different ways of transmission of SARS and MERS Coronavirus in different settings.

\section{Identification and Selection of Studies}

We had searched the electronic databases, MEDLINE, EMBASE, Science Citation Index, WHO reports, news (up to $30^{\text {th }}$ March, 2020). We had searched using the keywords, always in combination with "SARS-CoV-2" or "novel coronavirus 2019", "SARS" or "MERS" and "respiratory droplet", "aerosol transmission", "persistence in environment", "survival surface", "survival in clothes and shoes", "perinatal transmission", "feco-oral transmission", "ocular surface transmission", "transfusion transmission", "potential route of transmission" and the full text of any articles that appeared relevant was retrieved. We also searched for relevant studies by screening titles and abstracts listed in the WHO SARS-CoV-2 bibliography, by checking lists of references in relevant studies (all included studies and reviews), editorial, and personal communication.

\section{Data Extraction and Assessment of Methodological Quality}

Relevant data from each of the individual studies were extracted by one reviewer and verified by other reviewers using the predesigned data extraction form to capture the study characteristics and the outcome of interest. The study characteristics included information about the origin of the study, the period of evaluation, the population and types of laboratory tests to confirm the diseases. The outcome of interest was the risk of transmission of SARS-CoV-2, SARS-CoV and MERS$\mathrm{CoV}$ infections from patients to HCWs (health care workers) and general populations. Any disagreements between reviewers were resolved by consensus. An 
independent third reviewer was available to determine final data extraction in instances where consensus could not be reached. The appropriateness of pooling of data was determined based upon the degree of clinical and statistical heterogeneity between trials.

\section{Result}

A total number of 110 publications were included in this review. 55 studies were conducted in different countries (Table-1). Most of the studies were conducted in China.
14 were WHO reports, 37 were review articles and 5 were news reports. The objectives, type of patients, and the health care setting varied among studies making it difficult to generalize the results. Some studies were carried out under 'ideal' settings or in patient populations that are not representative of those presenting to health care facilities. Most of the studies were conducted in China (26). Other studies include populations from Hong Kong (11), Saudi Arabia (5), USA (3), Korea (2), Germany (3), Singapore (2) and one each from Canada, France and Oman.

\section{Table 1: List of Studies}

\begin{tabular}{|c|c|c|c|c|c|c|}
\hline Author name & Country & Study design & $\begin{array}{l}\text { Period of } \\
\text { evaluation }\end{array}$ & Population & Laboratory test & Reference \\
\hline Wang et al & China & $\begin{array}{l}\text { Retrospective } \\
\text { single centre } \\
\text { case series }\end{array}$ & $\begin{array}{l}\text { January } 1 \text { to } \\
\text { Feb 3, } 2020\end{array}$ & $\begin{array}{l}138 \text { hospitalized } \\
\text { COVID-19 } \\
\text { patients }\end{array}$ & rRT-PCR & 15 \\
\hline Lu et al & China & Cross sectional & 2019 & $\begin{array}{l}9 \text { COVID-19 } \\
\text { patients }\end{array}$ & $\begin{array}{l}\text { Next generation } \\
\text { sequencing }\end{array}$ & 20 \\
\hline Lau et al & Hong Kong & Cross sectional & $2004-2005$ & 59 horseshoe Bat & $\begin{array}{l}\text { rRT-PCR, DNA } \\
\text { sequencing, } \\
\text { Viral culture, } \\
\text { EIA, Genome } \\
\text { sequencing }\end{array}$ & 28 \\
\hline Nowotny et al & Oman & Cross sectional & 2013 & $\begin{array}{l}76 \text { Dromedary } \\
\text { camel }\end{array}$ & $\begin{array}{l}\text { Specific serum } \\
\text { IgG by protein } \\
\text { microarray, } \\
\text { Viral } \\
\text { neutralization } \\
\text { test }\end{array}$ & 29 \\
\hline Lau et al & China & $\begin{array}{l}\text { Cross sectional } \\
\text { analytical }\end{array}$ & 2017 & 1964 Bat samples & $\begin{array}{l}\text { rRT-PCR, Viral } \\
\text { culture }\end{array}$ & 30 \\
\hline Ding et al & China & $\begin{array}{l}\text { Cross sectional } \\
\text { observational }\end{array}$ & 2003 & $\begin{array}{l}\text { Autopsy samples } \\
\text { of organs from } 4 \\
\text { patients died of } \\
\text { SARS and } 4 \\
\text { control patients } \\
\text { died of other } \\
\text { disease }\end{array}$ & $\begin{array}{l}\text { ICH, ISH, RT- } \\
\text { PCR, } \\
\text { Transmission } \\
\text { electron } \\
\text { microscopy }\end{array}$ & 36 \\
\hline Oboho et al & Saudi Arabia & $\begin{array}{l}\text { Descriptive } \\
\text { analysis }\end{array}$ & 2014 & $\begin{array}{l}255 \text { patients with } \\
\text { laboratory } \\
\text { confirmed MERS }\end{array}$ & $\begin{array}{l}\text { Review of } \\
\text { medical records }\end{array}$ & 40 \\
\hline Alanazi et al & Saudi Arabia & Cross sectional & 2014 & $\begin{array}{l}\text { Total } 48 \text { cases by } \\
\text { contact tracing of } \\
\text { MERS cases } \\
\text { admitted into } 2 \\
\text { hospitals }\end{array}$ & $\begin{array}{l}\text { rRT-PCR, } \\
\text { Genome } \\
\text { sequencing }\end{array}$ & 41 \\
\hline Lee et al & Hong Kong & Prospective & $\begin{array}{l}\text { March 11 to } \\
25,2003\end{array}$ & $\begin{array}{l}66 \text { male, } 72 \\
\text { female SARS } \\
\text { patients }\end{array}$ & $\begin{array}{l}\text { rRT-PCR, Virus } \\
\text { culture }\end{array}$ & 42 \\
\hline Poissy et al & France & Prospective & 2013 & $\begin{array}{l}2 \text { hospital admitted } \\
\text { MERS patient }\end{array}$ & rRT-PCR & 45 \\
\hline Bin et al & South Korea & Prospective & $\begin{array}{l}8 \text { June } 2015 \text { to } \\
3 \text { July } 2015\end{array}$ & $\begin{array}{l}4 \text { MERS-CoV } \\
\text { patients in } 2 \\
\text { hospitals }\end{array}$ & $\begin{array}{l}\text { rRT-PCR, Virus } \\
\text { isolation by cell } \\
\text { culture }\end{array}$ & 46 \\
\hline Chan et al & Hong Kong & Prospective & $\begin{array}{l}\text { April,2003 to } \\
\text { May } 2004\end{array}$ & $\begin{array}{l}\text { hospitalized SARS } \\
\text { patients }\end{array}$ & rRT-PCR & 47 \\
\hline Guang et al & China & Retrospective & 2003 & $\begin{array}{l}\text { a total } 1,112 \\
\text { contactors of } \\
\text { SARS }\end{array}$ & $\begin{array}{l}\text { SARS-CoV Ab } \\
\text { by neutralization } \\
\text { test and ELISA } \\
\text { method }\end{array}$ & 48 \\
\hline
\end{tabular}




\begin{tabular}{|c|c|c|c|c|c|c|}
\hline Chan et al & China & Prospective & January 2020 & $\begin{array}{l}5 \text { patients in a } \\
\text { family cluster with } \\
\text { unexplained } \\
\text { Pneumonia }\end{array}$ & rRT-PCR & 49 \\
\hline Liu et al & China & Retrospective & January 2020 & $\begin{array}{l}365 \text { laboratory } \\
\text { confirmed cases of } \\
\text { COVID-19 }\end{array}$ & rRT-PCR & 50 \\
\hline Li et al & China & Retrospective & January 2020 & $\begin{array}{l}\text { 1at } 425 \text { cases of } \\
\text { confirmed novel } \\
\text { coronavirus } \\
\text { infected } \\
\text { pneumonia (NCIP) }\end{array}$ & rRT-PCR & 51 \\
\hline Huang et al & China & Prospective & January 2020 & $\begin{array}{l}41 \text { Hospital } \\
\text { admitted } \\
\text { confirmed cases of } \\
\text { COVID-19 }\end{array}$ & rRT-PCR & 52 \\
\hline Rothe et al & Germany & Case report & January 2020 & $\begin{array}{l}\text { A } 33 \text { year old } \\
\text { german man }\end{array}$ & rRT-PCR & 55 \\
\hline Li et al & China & Prospective & Jan 31 to fab 3 & $\begin{array}{l}\text { A Family cluster } \\
\text { of } 4 \text { patients }\end{array}$ & r RT-PCR & 57 \\
\hline Young et al & Singapore & $\begin{array}{l}\text { Descriptive case } \\
\text { series }\end{array}$ & Jan 23 to Feb 3 & $\begin{array}{l}\text { First } 18 \text { COVID- } \\
19 \text { cases in } 4 \\
\text { hospitals }\end{array}$ & rRT-PCR & 59 \\
\hline Chang et al & China & Retrospective & $\begin{array}{l}\text { Jan 28th to Feb } \\
\text { 9th, } 2020\end{array}$ & $\begin{array}{l}16 \text { confirmed } \\
\text { COVID-19 } \\
\text { patients }\end{array}$ & rRT-PCR & 60 \\
\hline Booth et al & Canada & $\begin{array}{l}\text { Cross sectional } \\
\text { observational }\end{array}$ & March, 2003 & $\begin{array}{l}\text { environmental } \\
\text { sample }\end{array}$ & rRT-PCR & 62 \\
\hline $\begin{array}{l}\text { Van } \\
\text { Doremalen et } \\
\text { al }\end{array}$ & USA & $\begin{array}{l}\text { Cross sectional } \\
\text { observational }\end{array}$ & 2012 & $\begin{array}{l}\text { MERS-CoV } \\
\text { (isolate HCoV- } \\
\text { EMC/2012) strain } \\
\text { studied }\end{array}$ & viral culture & 63 \\
\hline $\begin{array}{l}\text { Van } \\
\text { Doremalen et } \\
\text { al }\end{array}$ & USA & $\begin{array}{l}\text { Cross sectional } \\
\text { observational }\end{array}$ & January 2020 & $\begin{array}{l}\text { SARS-CoV-2 } \\
\text { nCoV-WA1-2020 } \\
\text { (MN985325.1) and } \\
\text { SARS-CoV-1 Tor2 } \\
\text { (AY274119.3) } \\
\text { strain studied }\end{array}$ & viral culture & 64 \\
\hline Ong et al & Singapore & Prospective & $\begin{array}{l}\text { Jan } 24 \text { to Feb } \\
4,2020\end{array}$ & $\begin{array}{l}3 \text { confirmed } \\
\text { hospitalised } \\
\text { COVID-19 cases }\end{array}$ & rRT-PCR & 67 \\
\hline Bin et al & South Korea & Prospective & $\begin{array}{l}8 \text { June to } 3 \text { July } \\
2015\end{array}$ & $\begin{array}{l}4 \text { MERS infected } \\
\text { patients. }\end{array}$ & $\begin{array}{l}\text { rRT-PCR } \\
\text { viral culture }\end{array}$ & 68 \\
\hline Xiao et al & Hong Kong & $\begin{array}{l}\text { Cross sectional } \\
\text { observational } \\
\text { (Detailed } \\
\text { modelling } \\
\text { study/Multi } \\
\text { agent model) }\end{array}$ & March 2003 & & $\begin{array}{l}\text { bioinformatic } \\
\text { analysis }\end{array}$ & 69 \\
\hline Chan et al & Hong Kong & $\begin{array}{l}\text { Cross sectional } \\
\text { observational }\end{array}$ & 2010 & $\begin{array}{l}\text { HKU39849 SARS- } \\
\text { CoV viral strain }\end{array}$ & Virus culture & 71 \\
\hline Duan et al & China & $\begin{array}{l}\text { Cross sectional } \\
\text { observational }\end{array}$ & 2003 & $\begin{array}{l}\text { A total of 10(6) } \\
\text { TCID50 viruses } \\
\text { (SARS } \\
\text { coronavirus strain } \\
\text { CoV-P9) were } \\
\text { placed in each } \\
\text { tested condition }\end{array}$ & Virus culture & 72 \\
\hline Rabenau et al & Germany & $\begin{array}{l}\text { Cross sectional } \\
\text { observational }\end{array}$ & 2003 & $\begin{array}{l}\text { SARS-CoV isolate } \\
\text { FFM-1 from }\end{array}$ & virus culture & 73 \\
\hline Lai et al & Hong Kong & Prospective & $\begin{array}{l}\text { SARS outbreak } \\
\text { in } 2003\end{array}$ & $\begin{array}{l}\text { a hospital admitted } \\
\text { SARS patient }\end{array}$ & virus culture & 74 \\
\hline Assiri & Saudi Arabia & Descriptive & $\begin{array}{l}\text { 1 September, } \\
2012 \text { to } 15\end{array}$ & $\begin{array}{l}47 \text { laboratory } \\
\text { confirmed cases of }\end{array}$ & rRT-PCR & 78 \\
\hline
\end{tabular}




\begin{tabular}{|c|c|c|c|c|c|c|}
\hline & & & June, 2013 & MERS & & \\
\hline Zing et al & China & Prospective & $\begin{array}{l}\text { Jan } 17 \text { to } \\
\text { March 6, } 2020\end{array}$ & $\begin{array}{l}3 \text { paediatric cases } \\
\text { of COVID-19 }\end{array}$ & rRT-PCR & 80 \\
\hline Holshue et al & China & Case report & January 2020 & $\begin{array}{l}\text { A } 35 \text { years old } \\
\text { male COVID-19 } \\
\text { case }\end{array}$ & rRT-PCR & 81 \\
\hline Wu et al & China & Prospective & $\begin{array}{l}\text { Jan } 16 \text { to } \\
\text { March } 15,2020\end{array}$ & $\begin{array}{l}98 \text { hospital } \\
\text { admitted } \\
\text { confirmed cases of } \\
\text { COVID-19 }\end{array}$ & rRT-PCR & 82 \\
\hline Wang et al & China & Prospective & $\begin{array}{l}\text { Jan } 1 \text { to Feb } \\
17,2020\end{array}$ & $\begin{array}{l}\text { Hospital admitted } \\
\text { confirmed } \\
\text { COVID-10 cases }\end{array}$ & rRT-PCR & 83 \\
\hline Zhang et al & China & $\begin{array}{l}\text { Cross sectional } \\
\text { study }\end{array}$ & Jan 2020 & $\begin{array}{l}\text { A hospital } \\
\text { admitted } \\
\text { laboratory } \\
\text { confirmed case of } \\
\text { COVID-19 }\end{array}$ & rRT-PCR & 84 \\
\hline $\mathrm{Xu}$ et al & China & $\begin{array}{l}\text { Cross sectional } \\
\text { analytical study }\end{array}$ & 2019 & $\begin{array}{l}\text { Two public } \\
\text { databases and } \\
\text { single-cell } \\
\text { transcriptomes } \\
\text { from an } \\
\text { independent data } \\
\text { generated in- } \\
\text { house. }\end{array}$ & $\begin{array}{l}\text { Bioinformatics } \\
\text { analysis }\end{array}$ & 85 \\
\hline Alserehi et al & Saudi Arabia & Case report & 2016 & $\begin{array}{l}\text { A } 33 \text { yr old ICU } \\
\text { admitted MERS } \\
\text { patient }\end{array}$ & rRT-PCR & 87 \\
\hline Creanga et al & USA & Case control & $\begin{array}{l}\text { May to June } \\
2009\end{array}$ & $\begin{array}{l}62 \text { pregnant } \\
\text { women with } \\
\text { laboratory- } \\
\text { confirmed } 2009 \\
\text { H1N1 influenza }\end{array}$ & rRT-PCR & 88 \\
\hline Lam et al & Hong Kong & $\begin{array}{l}\text { Case control } \\
\text { study }\end{array}$ & $\begin{array}{l}15 \text { Feb to } 31 \\
\text { May in } 2003\end{array}$ & $\begin{array}{l}10 \text { pregnant SARS } \\
\text { patient as case and } \\
40 \text { non pregnant } \\
\text { SARS patient as } \\
\text { control }\end{array}$ & $\begin{array}{l}\text { rRT-PCR, } \\
\text { SARS CoV Ab }\end{array}$ & 90 \\
\hline Assiri & Saudi Arabia & Retrospective & $\begin{array}{l}\text { Nov } 2012 \text { to } \\
\text { Feb } 2016\end{array}$ & $\begin{array}{l}5 \text { pregnant women } \\
\text { with MERS }\end{array}$ & rRT-PCR & 91 \\
\hline Wang et al & China & $\begin{array}{l}\text { Prospective } \\
\text { study }\end{array}$ & Jan 2020 & $\begin{array}{l}\text { Single COVID-19 } \\
\text { patient pregnant } \\
\text { women }\end{array}$ & rRT-PCR & 93 \\
\hline Zhu et al & China & $\begin{array}{l}\text { Retrospective } \\
\text { analytical study }\end{array}$ & $\begin{array}{l}\text { 20 Jan to Feb } \\
5,2020\end{array}$ & $\begin{array}{l}10 \text { neonates born } \\
\text { from diagnosed } \\
\text { COVID-19 } \\
\text { mothers }\end{array}$ & rRT-PCR & 94 \\
\hline Fan et al & China & $\begin{array}{l}\text { Prospective } \\
\text { study }\end{array}$ & Feb 2020 & $\begin{array}{l}2 \text { cases of hospital } \\
\text { admitted COVID- } \\
19 \text { cases in 3rd } \\
\text { trimester }\end{array}$ & $\begin{array}{l}\text { Real time RT- } \\
\text { PCR for } 3 \text { target } \\
\text { genes of SARS- } \\
\text { CoV-2 }\end{array}$ & 95 \\
\hline Chen et al & China & $\begin{array}{l}\text { Retrospective } \\
\text { review }\end{array}$ & Feb 2020 & $\begin{array}{l}9 \text { pregnant } \\
\text { confirmed cases of } \\
\text { COVID-19 }\end{array}$ & rRT-PCR & 96 \\
\hline Drosten et al & Germany & Case control & $\begin{array}{l}\text { March } 5 \text { to } \\
\text { March } 27\end{array}$ & $\begin{array}{l}18 \text { suspected } \\
\text { SARS patients }\end{array}$ & $\begin{array}{l}\text { rRT-PCR } \\
\text { sequencing }\end{array}$ & 99 \\
\hline Grant et al & Hong Kong & Prospective & 2003 & $\begin{array}{l}26 \text { hospitalized } \\
\text { SARS patient }\end{array}$ & RT-PCR & 100 \\
\hline $\mathrm{Ng}$ et al & Hong Kong & Prospective & $\begin{array}{l}\text { March to May } \\
2003\end{array}$ & $\begin{array}{l}35 \text { hospitalized } \\
\text { confirmed SARS } \\
\text { patients }\end{array}$ & rRT-PCR & 101 \\
\hline $\mathrm{Ng}$ et al & Hong Kong & Prospective & $\begin{array}{l}\text { March } 13 \text { to } \\
\text { May 17, } 2003\end{array}$ & $\begin{array}{l}8 \text { paediatric SARS } \\
\text { patients }\end{array}$ & $\begin{array}{l}\text { Real time RT } \\
\text { PCR, SARS } \\
\text { CoV IgG Ab } \\
\end{array}$ & 102 \\
\hline Huang et al & China & Prospective & January 2020 & 41 confirmed & rRT-PCR, Next & 105 \\
\hline
\end{tabular}




\begin{tabular}{|c|c|c|c|c|c|c|}
\hline & & study & & $\begin{array}{l}\text { hospital admitted } \\
\text { COVID-19 cases }\end{array}$ & $\begin{array}{l}\text { generation } \\
\text { sequencing }\end{array}$ & \\
\hline Chan et al & Hong Kong & $\begin{array}{l}\text { Cross sectional } \\
\text { study }\end{array}$ & January 2020 & $\begin{array}{l}5 \text { patients in a } \\
\text { family cluster }\end{array}$ & $\begin{array}{l}\text { point of care } \\
\text { multiplex PCR }\end{array}$ & 107 \\
\hline Xia et al & China & $\begin{array}{l}\text { Prospective } \\
\text { interventional } \\
\text { case series study }\end{array}$ & Jan 26 to Feb 9 & $\begin{array}{l}30 \text { confirmed cases } \\
\text { of nCoV } \\
\text { pneumonia }\end{array}$ & rRT-PCR & 109 \\
\hline Sun et al & China & $\begin{array}{l}\text { Single centre } \\
\text { cross sectional } \\
\text { study }\end{array}$ & $\begin{array}{l}\text { Dec } 30 \text { to Feb } \\
7\end{array}$ & $\begin{array}{l}\text { hospital admitted } \\
\text { COVID-19 } \\
\text { patients }\end{array}$ & rRT-PCR & 110 \\
\hline Xu et al & China & $\begin{array}{l}\text { Cross sectional } \\
\text { non randomized }\end{array}$ & January 2020 & $\begin{array}{l}\text { Diagnosed and } \\
\text { suspected cases of } \\
\text { COVID } 19\end{array}$ & rRT-PCR & 111 \\
\hline
\end{tabular}

Table 2. Stability of SARS-CoV-2, SARS-CoV and MERS-CoV on different environmental surface

\begin{tabular}{|c|c|c|c|c|c|c|}
\hline $\begin{array}{l}\text { Types of } \\
\text { surface }\end{array}$ & Virus & Strain & $\begin{array}{c}\text { Load } \\
\text { applied }\end{array}$ & Temperature & Persistence & Reference \\
\hline Plastic & $\begin{array}{l}\text { SARS-CoV-2 } \\
\text { SARS-CoV } \\
\text { SARS-CoV } \\
\text { MERS-CoV }\end{array}$ & $\begin{array}{l}\text { nCoV-WA1- } \\
\text { 2020(MN985325.1) } \\
\text { Tor 2(AY274119.3) } \\
\text { Strain HKU39849 } \\
\text { Isolated HCoV-EMC/2012 }\end{array}$ & $\begin{array}{c}10^{5.25} \\
10^{6.75-7} \\
10^{5} \\
10^{5}\end{array}$ & $\begin{array}{l}\text { Not specified } \\
\qquad \begin{array}{l}22-25 \\
20^{\circ} \mathrm{C} \\
30^{\circ} \mathrm{C}\end{array}\end{array}$ & $\begin{array}{c}72 \mathrm{~h} \\
\leq 5 \mathrm{~d} \\
48 \mathrm{~h} \\
8-24 \mathrm{~h}\end{array}$ & $\begin{array}{l}64 \\
71 \\
63\end{array}$ \\
\hline $\begin{array}{l}\text { Stainless } \\
\text { Steel }\end{array}$ & $\begin{array}{l}\text { SARS-CoV-2 } \\
\text { SARS-CoV } \\
\text { MERS-CoV }\end{array}$ & $\begin{array}{l}\text { nCoV-WA1- } \\
\text { 2020(MN985325.1) } \\
\text { Tor 2(AY274119.3) } \\
\text { Isolated HCoV-EMC/2012 }\end{array}$ & $\begin{array}{c}10^{5.25} \\
10^{6.75-7} \\
10^{5}\end{array}$ & $\begin{array}{l}\text { Not specified } \\
\qquad \begin{array}{l}20^{\circ} \mathrm{C} \\
30^{\circ} \mathrm{C}\end{array}\end{array}$ & $\begin{array}{c}48 \mathrm{~h} \\
48 \mathrm{~h} \\
8-24 \mathrm{~h}\end{array}$ & $\begin{array}{l}64 \\
64 \\
63\end{array}$ \\
\hline Copper & $\begin{array}{l}\text { SARS-CoV-2 } \\
\text { SARS-CoV }\end{array}$ & $\begin{array}{l}\text { nCoV-WA1- } \\
\text { 2020(MN985325.1) } \\
\text { Tor 2(AY274119.3) }\end{array}$ & $\begin{array}{c}10^{5.25} \\
10^{6.75-7}\end{array}$ & Not specified & $\begin{array}{l}4 \mathrm{~h} \\
8 \mathrm{~h} \\
\end{array}$ & $\begin{array}{l}64 \\
64 \\
\end{array}$ \\
\hline Cardboard & $\begin{array}{l}\text { SARS-CoV-2 } \\
\text { SARS-CoV }\end{array}$ & $\begin{array}{l}\text { nCoV-WA1- } \\
\text { 2020(MN985325.1) } \\
\text { Tor 2(AY274119.3) }\end{array}$ & $\begin{array}{l}10^{5.25} \\
10^{6.75-7}\end{array}$ & Not specified & $\begin{array}{l}24 \mathrm{~h} \\
8 \mathrm{~h}\end{array}$ & $\begin{array}{l}64 \\
64\end{array}$ \\
\hline Glass & SARS-CoV & Strain P9 & $10^{5}$ & RT & $4 \mathrm{~d}$ & 72 \\
\hline Metal & SARS-CoV & Strain P9 & $10^{5}$ & RT & $5 \mathrm{~d}$ & 72 \\
\hline Wood & SARS-CoV & Strain P9 & $10^{5}$ & RT & $4 \mathrm{~d}$ & 72 \\
\hline $\begin{array}{l}\text { Polystyrene } \\
\text { Petri Dish }\end{array}$ & SARS-CoV & & $10^{6-7}$ & RT & $>6 \mathrm{~d}$ & 73 \\
\hline Paper & $\begin{array}{l}\text { SARS-CoV } \\
\text { SARS-CoV }\end{array}$ & $\begin{array}{l}\text { Strain P9 } \\
\text { Strain GVU6109 }\end{array}$ & $\begin{array}{l}10^{5} \\
10^{6} \\
10^{5}\end{array}$ & $\begin{array}{l}\text { RT } \\
\text { RT }\end{array}$ & $\begin{array}{c}4 \mathrm{~d} \\
24 \mathrm{~h} \\
3 \mathrm{~h}\end{array}$ & $\begin{array}{l}72 \\
74\end{array}$ \\
\hline $\begin{array}{l}\text { Disposable } \\
\text { Gown }\end{array}$ & SARS-CoV & Strain GVU6109 & $\begin{array}{l}10^{6} \\
10^{5}\end{array}$ & RT & $\begin{array}{c}2 \mathrm{~d} \\
24 \mathrm{~h}\end{array}$ & 74 \\
\hline
\end{tabular}

RT= Room Temperature

\section{Reservoir and Animal to Human Transmission}

In order to develop preventive strategies to contain the infection it is fundamental to determine the host of origination and route of transmission. In December, 2019, clusters of atypical pneumonia with unknown etiology were identified in Wuhan city of China which was epidemiologically linked to a seafood wholesaler market $^{18}$. Virus isolation from patients and rapid sequence analysis revealed that the pathogen is a novel beta corona virus which showed $96.2 \%$ overall genome sequence homology with Bat CoV RaTG13, 79.6\% similarity with SARS-CoV ${ }^{19}$ and only $50 \%$ identity to MERS-CoV ${ }^{20}$. Different studies have demonstrated that bats harbor a wide variety of CoVs including SARS related-CoV and MERS related-CoV suggesting that immediate ancestor SARS-CoV-2 has been circulating in bats for several years. It requires further confirmation whether SARS-CoV-2 is directly transmitted from bat to human or through an intermediate host ${ }^{21}$. Several other animals like turtles, pangolin snakes and many species showed sequence homology of receptor residues of SARS-CoV-2 which strengthens the possibility of presence of an intermediate host. So far, the intermediate hosts of SARS-CoV-2 are elusive and pangolins, snakes, minks are reported to be the plausible host ${ }^{22}$. Recently, a research group of South China Agricultural University analyzed more than 1,000 metagenomic samples and reported that $70 \%$ of pangolins were positive for the coronavirus $^{23}$. Sequence analysis of the strain found in pangolin showed $97 \%$ sequence homology in the Receptor Bindings Domain (RBD) with the current infected human strain SARS-CoV-2 ${ }^{24}$. Another group of researchers observed that a unique peptide (PRRA) insertion is present in the human SARS-CoV-2 virus, which is absent in pangolin originated strain and they 
concluded that SARS-CoV-2 may not be directly come from pangolin to human host ${ }^{25}$. To determine what this intermediate host species might be it is imperative to perform far wider sampling of animals from wet markets or that live close to human populations. In case of SARS$\mathrm{CoV}$, phylogenetic analysis showed that it is a beta corona virus and closely related to the CoVs found in civets, raccoon dogs, ferret badgers and Chinese horseshoe bats (Rhinolophus sinicus) in Guangdong Province of South China where initial epidemic was breaking out in $2002^{26}$. Researchers initially thought that civets or raccoon dogs are the primary reservoir hosts which are sold in Chinese wet market as a food source. Later on, the Chinese horseshoe bat appears to be the natural reservoir of the ancestral SARS-CoV, because the mutation rates of different genes of the strains found in bats were low, while rapidly evolving process of adaptation of a viral strain in animals evident by high mutation rate were observed in those of the civet strains $^{27,28}$. It may indicate an interspecies transmission from bats to intermediate hosts like civets and finally to humans. MERS-CoV is another highly pathogenic zoonotic CoV that was identified in Saudi Arabia in 2012. MERS-CoV-like virus was identified in Pipistrellus and Perimyostis bats suggesting that bats are the potential reservoir and transmitting host. Studies have shown that dromedary camel MERS-CoV strains are almost identical to human MERS-CoV, proffering that MERS-CoV was transmitted from bat to camel, an intermediate host then to terminal human host ${ }^{29}$. Sequence analysis revealed that strain of MERS-CoV found in bat had $60-70 \%$ homology to camel and human MERS-CoV postulated that it had to undergo several amino acid changes in receptor binding protein to become capable of infecting camel and human host $\mathrm{t}^{30-31}$.

\section{Human to Human Transmission}

Sustained human to human transmission is necessary to establish a transmission cycle and to initiate an outbreak. An efficient human to human transmission requires the ability of the virus to attach to human cells. Corona viruses attach to the host cell via spike protein ${ }^{32}$. Human angiotensin converting enzyme 2 (ACE-2) is shown to be the receptor of SARS-CoV-2 and SARS-CoV, ${ }^{33}$ whereas MERS-CoV uses dipeptidyl peptidase 4 (DPP-4) receptor to enter into host cell ${ }^{34}$. Apparently SARS-CoV2, MERS-CoV and SARS-CoV all three highly pathogenic corona viruses spread efficiently using multiple routes among humans. Airborne transmission via droplets and contact with contaminated surfaces are the accepted transmission route, whereas aerosol transmission, feco-oral transmission, perinatal, blood borne transmission are the plausible routes of transmission of highly pathogenic $\mathrm{CoVs}^{35-37}$.

\section{Respiratory Droplet Transmission}

Direct contact transmission via respiratory droplet is the most frequent and established route of transmission of respiratory viruses where droplets $(>5 \mu \mathrm{m}$ diameter, travelling $<1 \mathrm{~m}$ ) containing viable viruses may produce during expiratory activities like talking, coughing, sneezing and laughing. This droplet may come in contact with the nose, mouth, eyes, or upper respiratory tract of susceptible individuals who come in close proximity to the infected person and eventually they become infected $^{38}$. Droplet transmission appears to be a major route of transmission of SARS-CoV and MERS-CoV. Primarily cases were detected in household and hospital settings in persons who remain in close contact with the SARS-CoV and MERS-CoV infected patients ${ }^{39-43}$. Occasional transmission also documented among casual and social contacts after prolonged and intense exposure to a SARS-CoV case ${ }^{44}$. Both upper (nasopharyngeal and oropharyngeal swab) and lower (sputum, tracheal aspirate, and bronchoalveolar lavage fluid) respiratory tract samples gave positive results for MERS-CoV RNA and live virus. Prolonged period of viral shedding through respiratory route was also documented during MERS-CoV outbreak which was evident by detection of viral RNA for more than 1 months and live virus up to 25 days in a few cases after onset of symptoms ${ }^{45-46}$.

SARS-CoV RNA in respiratory samples of infected patients became detectable within 4 days, gradually increasing from 6 to11 days of symptom onset and started to decline after 16 days but in some patient RNA was detectable for $>30$ days whereas virus could be isolated up to first 2 weeks of the illness and generally become negative after 3 weeks ${ }^{47}$. SARS-CoV and MERS-CoV infected patients remain infectious during their symptomatic period. Transmission of SARS-CoV and MERS-CoV during incubation period or from asymptomatic patients was not reported till today ${ }^{37,48}$. Up to present, all the evidence indicates that droplet transmission among close contacts is the main transmission route of SARS-CoV-2 ${ }^{49-52}$. Four generations of spread (first case acquired this infection from a nonhuman source who infected someone else, who infected another individual, who then infected another individual) of SARS-CoV-2 was identified suggesting that sustained human to human transmission cycle has already been established ${ }^{53-54}$. SARS-CoV infected patients may transmit the virus during their early phase of infection and asymptomatic carriers also seem to be infectious ${ }^{55-57}$.

SARS-CoV-2 RNA was detected from upper respiratory tract samples prior 21-2 days of symptoms onset and continue to persist for 7 to 12 days and in some severe cases up to 2 weeks ${ }^{58}$. In Singapore prolonged persistence of viral shedding, at least for 24 days in nasopharyngeal swab was recorded ${ }^{59}$. Researchers observed that Virus continues to shed up to 8 days in respiratory samples after apparent resolution of symptoms ${ }^{60}$. So far, it is not clearly evident how long SARS-CoV infected patients remain infectious.

\section{Aerosol Transmission}

Aerosols also known as 'droplet nuclei' which are small particles of $\leq 5 \mu \mathrm{m}$ diameter and can travel $>1 \mathrm{~m}$, usually produced through the process of rapid drying up of 
exhaled respiratory droplets ${ }^{38}$. Aerosol transmissible infectious agents have two key features a) their tendency to follow air flows and remain suspended in the air for prolonged period of time which facilitates onwards transmission and b) their small size, which requires an enhanced filtering capacity. Moreover, it demands costly PPE (personal protective equipment) of healthcare providers that can tightly seal the airways while providing patients care or performing aerosol generating procedures $^{61}$. It is necessary to find out whether highly pathogenic CoVs are aerosol transmissible or not as route of transmission has significant implications on containment strategies of these infectious agents. Previous data regarding transmission of SARS-CoV and MERS-CoV suggested that major route of transmission was respiratory droplet and close contact but aerosol transmission may have played some role in nosocomial and super spreading events during outbreak ${ }^{61-63}$. It is still controversial whether SARS-CoV-2 transmitted through aerosol or not besides respiratory droplet. In a recent study, aerosol containing SARS-CoV-2 and SARS-CoV were generated with the use of a three jet collision nebulizer and fed into a Goldberg drum to create an artificial aerosolized environment. Both SARS-CoV-2 and SARS-CoV remained viable up to 3 hours in the suspended air suggesting that these highly pathogenic viruses may have the potential to be transmitted through aerosol and higher chances of nosocomial infection ${ }^{64}$. WHO recommended "airborne precautions" for healthcare workers in specific circumstances that generate aerosol (i.e. endotracheal intubation, bronchoscopy, open suctioning, administration of nebulized treatment, manual ventilation before intubation, turning the patient to the prone position, disconnecting the patient from the ventilator, noninvasive positive-pressure ventilation, tracheostomy, and cardiopulmonary resuscitation) though previous experiment that was conducted in artificial environment doesn't reflect normal human cough condition or clinical settings ${ }^{65}$. Besides that, different environmental condition such as UV light, humidity, temperature. also affect the viability of infectious agents which were not considered in recent study ${ }^{66}$. Another study demonstrated the presence of SARS-CoV-2 RNA in swab taken from the air exhaust outlets collected from COVID-19 positive patient's room before routine cleaning, suggested that virus containing small air droplets may be deposited though they did not observe the viability of virus. They also examined the SARS-CoV-2 RNA in air samples of that patient's room and all the air samples showed negative results for viral $\mathrm{RNA}^{67}$. Although there is not clear evident of aerosol transmission, but it should be considered as a potential route of transmission at least in special settings where aerosol generating procedures are performed and proper precautions should be adopted.

\section{Indirect Contact Transmission}

Inanimate objects that can be contaminated by infectious agents are known as fomites that serve as a medium for transfer of organisms between hosts. Indirect contact transmission is another major route of transmission of
SARS-CoV-2, SARS-CoV and MERS-CoV viruses. Infectious droplets of varying sizes are produced by breathing, coughing or sneezing of $\mathrm{CoV}$ infected patients and settled down onto different surfaces (fomites). When someone touches this contaminated surfaces, they can be infected by self-inoculating the coronaviruses into mucosal membranes like in the eyes, nose and mouth. In healthcare settings frequent touch surfaces act as a potential source of infection ${ }^{63,67-69}$. Several factors determine the potentiality of spread of CoVs through fomites such as stability of corona viruses on such surfaces, viral load, environmental condition and the infective susceptibility of the different exposed tissues of host. Analysis of several studies reveals that SARS-CoV and MERS-CoV have unusual capacity to survive on different inanimate surfaces for several hours to days like non-enveloped viruses ${ }^{70}$. Higher temperature reduces the duration of persistence of MERS-CoV whereas increase viral load increases the stability of SARS-CoV and MERS-CoV ${ }^{63,71}$. MERS-CoV detected on steel and plastic after 48 hours at $20^{\circ} \mathrm{C}$ whereas at $30^{\circ} \mathrm{C}$ viability reduced to 8 to 24 hours depending on humidity ${ }^{63}$. Currently a comparative study was conducted under laboratory condition between SARS-CoV-2 and SARS$\mathrm{CoV}$ showed that stability of both viruses is almost similar on plastic, stainless steel, copper and cardboard. Highest viability of SARS-CoV-2 observed on plastic that was 72 hours, on steel 48 hours, whereas no viable SARS-CoV-2 was found on cardboard after 24 hours ${ }^{64}$. SARS-CoV remains viable on polystyrene petri dish more than 6 days and on disposable gown from 5 min to 2 days depending on viral load ${ }^{73-74}$. So far there is no scientific study examined the viability of SARS-CoV-2 and MERS-CoV on fabrics. Porous fabrics like cardboard where SARS-CoV-2 survives for 24 hours, so it may remain viable on porous fabrics for at least 24 hours. But zipper, button which is made of steel, SARS$\mathrm{CoV}$, MARS-CoV and SARS-CoV-2 may survive for longer time. expertise suggested that polyester, spandex may retain virus more time than cotton fabrics as cotton fabrics are more porous which is beneficial. Porous fabrics can trap the virus containing droplets and suck out fluid which leads to loss of infectivity of virus ${ }^{75}$. Dr. Schmidt also warns that coronaviruses may survive on shoes and synthetic fabrics for 5 days though no study was published where viability of SARS-CoV-2 on shoes were examined till today ${ }^{76}$. Findings of different studies (Table-2) and valuable opinions of expertise highlighted that there is a higher chance of indirect contact transmission of SARS-CoV-2 via fomites.

\section{Feco-oral Transmission}

SARS-CoV and MERS-CoV have been reported to cause alimentary symptoms and presence of viral RNA was also detected in previous studies ${ }^{77-78}$. During the SARS outbreak back in 2002-2003, a study revealed presence of SARS-CoV RNA in patients' fecal specimens from the fifth day of disease which continued to rise and peaked at the 11th day. In a minor number of patients the viral RNA remained positive even after 30 days of disease onset $^{47}$. A study published in 2016 by Corman ${ }^{79}$ shows 
that $14.6 \%$ of fecal specimens from MERS-CoV infected patients were positive for viral RNA. Prolonged presence of SARS-CoV and MERS-CoV in fecal samples and their ability to withstand the various environmental conditions may facilitate their feco-oral transmission ${ }^{71}$. Till date, reports from Wuhan stated that 2 to $10 \%$ of COVID-19 patients have shown enteric symptoms like abdominal pain, diarrhoea and vomiting and patients who required ICU support presented with these symptoms more. Moreover, stool sample collected from confirmed cases of SARS-COV-2 infection in Wuhan China shows presence of viral $\mathrm{RNA}^{15}$. Prolonged shedding of SARS-CoV-2 RNA was reported among pediatrics children and it was observed that their throat swab became negative after 2 weeks of fever abatement whereas viral RNA remained persistent for 1-3 weeks after throat swab became negative ${ }^{80}$. The first patient diagnosed with COVID-19 in the United States was also checked for SARS-COV-2 RNA in his fecal sample which showed similar results ${ }^{81}$. Another study demonstrated that fecal specimens continued to be SARS-CoV-2 RNA positive for a mean of 11.2 days more than respiratory $\mathrm{swab}^{82}$. Importantly live virus has reportedly been cultured from stool samples besides viral RNA from COVID-19 patients ${ }^{83,84}$. Another study has revealed that expression of ACE-2 receptor in the oral cavity may facilitate the entry of SARS-CoV $-2^{85}$. Meanwhile it is quite obvious that SARS-COV-2 can live longer in the alimentary tract of the patients than the respiratory tract strongly suggests that there is a possibility of fecal oral transmission. Ingestion of food contaminated with viable virus or inhalation of droplets containing virus from stool is the suggested possible way of transmission from faces although the chance of transmission and infection by ingestion or inhalation need much more evaluation ${ }^{54,81}$.

\section{Perinatal Transmission}

It has been evident by previous studies that pregnant women are very much susceptible to viral infections including SARS-CoV and MERS-CoV which accounts for adverse pregnancy outcomes like increased mortality rate of pregnant women, miscarriage, preterm delivery, intrauterine growth retardation of fetus ${ }^{86-89}$. In spite of such adverse outcome of viral infection during pregnancy, no documentation of perinatal transmission of SARS-CoV and MERS-CoV from mother to fetus was

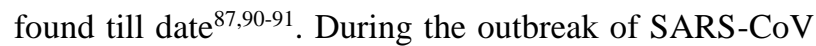
infection in 2002 RT-PCR and viral cultures of blood, cerebrospinal fluid, respiratory secretions, excreta, and other body fluids of newborns from SARS infected mother showed negative results for virus ${ }^{92}$. Very limited numbers of studies were conducted so far where transmissions of SARS-CoV-2 from mother to child in different potential routes were evaluated. A 28-year-old pregnant lady was diagnosed with COVID-19 at Suzhou Municipal Hospital who eventually underwent an emergency Cesarean Section at 30 weeks of gestation. Samples of placenta, umbilical cord blood, amniotic fluid, gastric juice and throat swab of the infant were obtained during the delivery and all the samples tested negative for SARS-CoV-2 RNA. Throat swab and stool specimen collected after 3 days of delivery showed the same result ${ }^{93}$. Huaping-Zhu ${ }^{94}$ also revealed similar negative results for SARS-CoV-2 nucleic acid in pharyngeal swabs collected from 9 neonates born from confirmed cases of COVID-1994. Cuifang and colleagues $^{95}$ reported two cases of COVID-19 positive pregnancy during the third trimester. Presence of SARSCoV-2 could not be detected by serial qRT-PCR in the products of conception and the neonates which supports the previous idea of limited possibility of the viral transmission through placenta or via ingestion of cervicovaginal fluid $^{95}$. A retrospective study was conducted by Chen and colleagues ${ }^{96}$ on 9 laboratory confirmed cases of COVID-19 pneumonia in Zhongnan Hospital of Wuhan University. From all the 9 live births, specimens of 6 newborns were tested and found negative for viral nucleic acid which indicates no transplacental entry into the fetus ${ }^{96}$. Despite all the evidence not in favour of perinatal transmission of SARS-CoV-2, some different scenarios demand attention. During the recent outbreak of SARS-CoV-2 infection in 2020, presence of viral RNA is detected after 30 hours of delivery in a pharyngeal swab obtained from a newborn of a confirmed case COVID-19 in Wuhan, China. This incident points to the possible risk of vertical transmission of the virus ${ }^{97}$. A similar case reported in Tongji Hospital suggests that the chance of vertical transmission of SARS-COV-2 is yet to be evaluated as definitive in a large scale ${ }^{98}$. Scarce information about clinical features and transmission of SARS-CoV-2 infection during pregnancy renders the necessity of further studies so that necessary preventive measures can be taken.

\section{Transmission via Transfusion}

As SARS-CoV-2 is highly infectious and spreading faster across the world hence every possible route of transmission should be considered. Though viral RNA was detectable in serum or plasma samples of patients infected with both in SARS-CoV and MERS-CoV $79,99,100$, but no transmission by blood or other substance of human origin have been documented to date ${ }^{101}$. In adult cases SARS-CoV RNA was detected in $78.0 \%$ cases during the first week of illness ${ }^{102}$. Another study on pediatrics SARS patients found out viremia in $87.5 \%$ of the cases ${ }^{103}$. Viral shedding in plasma was found to be common during the clinical course of SARS-CoV infection in 2003 and $79.0 \%$ cases became positive within 3 days of onset of fever with a peak rise around day 4-5, after which it was diminished ${ }^{102}$. Study on theoretical estimated risk of SARS-CoV transmission through blood transfusion revealed that the mean risk was 14.11 per million with maximum risk 23.57 per million $^{104}$. MERS-CoV infection is relatively more fatal and causes highly lethal respiratory distress as that of SARS $^{79}$. In a study it was observed that high viral load was detected in serum samples within the first week of diagnosis of MERS-CoV infection in some cases ${ }^{105}$. Similarly, SARS-CoV-2 infection also showed positive results for viral RNA in plasma or serum samples ${ }^{106}$. The 
infection caused SARS-CoV-2 is mainly diagnosed by the presence of viral RNA in the pharyngeal swab but viral nucleic acid has also been detected in the plasma of COVID-19 patients ${ }^{106}$. The first 41 confirmed cases of COVID-19 in Wuhan, China were investigated by Huang and colleagues and in $15.0 \%(6 / 41)$ cases viremia was detected. This study also revealed a very low plasma concentration of SARS-CoV-2 RNA both in case of patients under intensive care unit and patients having mild symptoms ${ }^{106}$. In another study, during this recent outbreak, 1 of 6 cases was found to have weak positive results for viral nucleic acid ${ }^{107}$. As there is so much yet to be discovered about the SARS-CoV-2 in every aspect and asymptomatic cases also account for the possibility of transmission ${ }^{108}$, it will be wise to reconsider the blood products as a potential source of infection according to the findings till now.

\section{Transmission via Conjunctiva}

Based on a recent case report and evidence of virus detection from the eye among cases with conjunctivitis, ocular surface is thought to be another possible route of transmission of SARS-CoV-2. A healthcare worker became infected with SARS-CoV-2 after visiting a patient wearing an N95 respirator, but no eye protection. Among 30 confirmed COVID-19 patients only one patients showed positive results for viral RNA in his tear and conjunctiva secretion ${ }^{109}$. In a cross-sectional study of 72 laboratory-confirmed cases of COVID-19, two patients $(2.8 \%)$ had conjunctivitis. Viral RNA fragments were identified in ocular discharges using a RT-PCR assay in one patient with conjunctivitis ${ }^{110}$. In another cross-sectional study, RT- PCR assays of conjunctival secretion were conducted on 14 confirmed cases and 16 suspect cases of COVID-19. All results were negative ${ }^{111}$. Ophthalmologist should be aware and take protective measure while providing care to a patient presented with conjunctivitis because ophthalmologists may be the first providers to evaluate patients possibly infected with COVID-19.

\section{Discussion}

The systematic review incorporated latest highly informative studies and evidence regarding established and potential routes of SARS-CoV-2 transmission. It also highlighted transmission of SARS-CoV and MERS$\mathrm{CoV}$ which caused outbreaks in the past. As SARS-CoV2 is highly infectious and spreading faster across the world hence every possible route of transmission should be considered.

Since the first reports of SARS-CoV-2 in the seafood market of Wuhan, China, there has been considerable discussion on the origin of the causative virus. Genome sequence analysis firmly determines that it originated from Bat, though it is still controversial whether an intermediate host exists or not like SAR-CoV and MERS-CoV ${ }^{19,20,21}$. So far, coronavirus identified in pangolin showed the highest level of similarities with human originated SARS-CoV highlighting its potential to act as an intermediate host ${ }^{24,25}$.

Transmission of SARS-CoV-2 has been documented to occur frequently and inevitably via respiratory droplets as the viable virus comes out from the infected person through expiratory activities and infects another person by direct contact. Sustained human to human transmission cycle has been established by detecting four generation spread of SARS-CoV-2. Moreover, detection of the viral RNA in the respiratory tract prior to the onset of symptoms and days after recovery makes this established route the prime one to consider ${ }^{51,52,53,54}$.

One study revealed that SARS-CoV-2 remained viable in the air for 3 hours after aerosol generating procedure in artificial settings ${ }^{65}$, whereas viral RNA was detected in air exhaust outlets of COVID-19 positives patients' rooms ${ }^{67}$. SARS-CoV and MERS-CoV also found to be persistent in the air after aerosol generating procedure suggested that at least in some instances where aerosol is generated, airborne precautions should be adopted to prevent transmission of SARS-CoV-2 (Table-2).

Studies conducted on survivability of SARS-CoV-2 on different surfaces confirmed that contaminated fomites are potential route of transmission of SARS-CoV-2 (Table-2). Therefore, hand washing before touching the mouth, nose and eyes after contact with contaminated surface is highly recommended.

The possibility of SARS-CoV-2 transmission through feco-oral route gained considerable attention as the fecal samples collected from patients of different ages and countries were positive for viral RNA as well as viable virus during the current outbreak ${ }^{15,83,84}$. Similar to SARS$\mathrm{CoV}$ and MERS-CoV, SARS-CoV-2 showed longer viability in the alimentary tract than the respiratory tract $^{80,81}$. A study suggested that expression of ACE-2 receptor in the oral cavity may facilitate the entry of SARS-CoV-2 which points to the strong potential of this route of transmission ${ }^{85}$.

Although no significant perinatal transmission of SARS$\mathrm{CoV}$ and MERS-CoV from mother to fetus was documented till date, these two viruses were found to cause several negative pregnancy outcomes ${ }^{86,87,88,89,90,91}$. The current COVID-19 outbreak allowed very few studies to be conducted regarding this issue. Most of them reported absence of viral RNA in products of conception as well as neonatal pharyngeal swab which suggest no transplacental entry of virus ${ }^{93,94,95,96}$. In contrast, we found two case reports from China where viral RNA was detected in the pharyngeal swab of the neonate ${ }^{97,98}$. Scarce information about perinatal transmission renders the necessity of further studies so that necessary preventive measures can be adopted.

Serum or plasma samples of patients infected with SARS-CoV and MERS-CoV have tested positive for viral RNA in many cases but transmission via blood 
products has not been documented so $\operatorname{far}^{79,99,100,101,102,103,104,105}$. We observed more or less similar picture while reviewing the studies of the recent COVID-19 outbreak. SARS-CoV-2 infection is mainly diagnosed by presence of viral RNA in the respiratory tract samples but few reports from China showed that it has also been detected in some patient's serum or plasma $^{106,107,108}$. As there is so much yet to be discovered about the SARS-CoV-2 in every aspect and asymptomatic cases cannot be completely spared from the possibility of transmission, it will be wise to reconsider the blood products as a potential source of infection.

Although recent studies revealed that viral RNA was detected in ocular secretions of very few COVID-19 patients and conjunctivitis was a rare clinical feature of current outbreaks ${ }^{109,110,111}$, ophthalmologists should consider the ocular surface as a potential route of transmission of SARS-CoV-2 and take necessary precautions while attending patients presented with conjunctivitis.

\section{Conclusion}

Until now, no promising clinical treatments or preventive strategies have been developed against newly emerging novel SARS-CoV-2. In this regard interruption of sustained human to human transmission is the best possible way to combat this deadly virus. Clear understanding of transmission routes and infectivity is essential so that appropriate protective measures can be adopted to prevent its spread. Epidemiologic observations and laboratory studies suggested that SARS-CoV-2 is highly infectious and mainly transmitted by close contact probably via droplets and contaminated fomites, but transmission via aerosols, feco-oral and other potential route should take into consideration in this current situation and appropriate protective measures should be employed to overcome the pandemic as soon as possible.

\section{References}

1. WHO. Coronavirus disease (COVID-19) outbreak. WHO health organization, 2020 https://www.who.int/emergencies/diseases/novelcoronavirus-2019 (accessed on 20 March 2020)

2. WHO. Named the New Pneumonia "COVID-19". Available online: http://www.xinhuanet.com/world/202002/12/c_1125561389.htm (accessed on 20 March 2020)

3. World meter. COVID-19 CORONAVIRUS PANDEMIC https://www.worldometers.info/coronavirus/(accessed on 20 March 2020)

4. WHO Director-General's opening remarks at the media briefing on COVID-19 $\quad-\quad 11 \quad$ March 2020 https://www.who.int/dg/speeches/detail/who-director-general-sopening-remarks-at-the-media-briefing-on-covid-19---11-march-2020 (accessed on 20 March 2020)

5. WHO. SARS (severe acute respiratory syndrome) https://www. who.int/ith/diseases/sars/en/(accessed on 21 March 2020)

6. WHO. Middle East respiratory syndrome coronavirus (MERS$\mathrm{CoV}$ ) https://www.who.int/emergencies/mers-cov/en/ (accessed on 21 March 2020)

7. Woo PC, Huang Y, Lau SK, Yuen KY. Coronavirus genomics and bioinformatics analysis. Viruses 2010;2:1804-1820
8. Su S, Wong G, Shi W, Liu J, Lai AC, Zhou J, et al. Epidemiology, genetic recombination, and pathogenesis of coronaviruses. Trends in Microbiology. 2016;24(6):490-502.

9. Cui J, Li F, Shi ZL. Origin and evolution of pathogenic coronaviruses. Nature reviews Microbiology. 2019;17(3):181-92

10. Yin Y, Wunderink RG. MERS, SARS and other coronaviruses as causes of pneumonia. Respirology. 2018;23(2):1307

11. Fan Y, Zhao k, Zhou P. Bat coronaviruses in china. Viruses. 2019;11:210

12. Otter JA, Donskey C, Yezli S, Douthwaite S, Goldenberg SD, Weber DJ. Transmission of SARS and MERS coronaviruses and influenza virus in healthcare settings: the possible role of dry surface contamination. Journal of Hospital Infection. 2016;92(3):235-50

13. Gralinski LE, Menachery VD. Return of the Coronavirus: 2019-nCoV. Viruses 2020;12:135

14. Li Q, Guan X, Wu P, Wang X, Zhou L, Tong Y, et al. Early transmission dynamics in Wuhan, China, of novel coronavirus-infected pneumonia. New England Journal of Medicine. 2020 Jan 29.

15. Wang D, Hu B, Hu C, Zhu F, Liu X, Zhang J, et al. Clinical characteristics of 138 hospitalized patients with 2019 novel coronavirus-infected pneumonia in Wuhan, China. JAMA. 2020 Feb 7. 16. Chan JF, Yuan S, Kok KH, To KK, Chu H, Yang J, et al. A familial cluster of pneumonia associated with the 2019 novel coronavirus indicating person-to-person transmission: a study of a family cluster. The Lancet. 2020;395(10223):514-23

17. Global infections number half a million https://www.nature.com/articles/d41586-020-00154-w(accessed on 22 March 2020)

18. Bogoch II, Watts A, Thomas-Bachli A, Huber C, Kraemer MU, Khan K. Pneumonia of Unknown Etiology in Wuhan, China: Potential for International Spread Via Commercial Air Travel. Journal of Travel Medicine. 2020 Jan 14.

19. Zhou P, Yang XL, Wang XG, Hu B, Zhang L, Zhang W, et al. A pneumonia outbreak associated with a new coronavirus of probable bat origin. Nature. 2020:1-4

20. Lu R, Zhao X, Li J, Niu P, Yang B, Wu H, et al. Genomic characterization and epidemiology of 2019 novel coronavirus: Implications for virus origins and receptor binding. Lancet. 2020;395:565-574

21. Sun J, He WT, Wang L, Lai A, Ji X, Zhai X, et al. COVID-19: epidemiology, evolution, and cross-disciplinary perspectives. Trends in Molecular Medicine. 2020 Mar 21.

22. Liu Z, Xiao X, Wei X, Li J, Yang J, Tan H, et al. Composition and divergence of coronavirus spike proteins and host ACE2 receptors predict potential intermediate hosts of SARS-CoV-2. Journal of Medical Virology. 2020 Feb 26.

23. South China Agricultural University: Pangolin May Be a Potential Intermediate Host of New Coronavirus. Available online: http://www.chinanews.com/sh/2020/0207/9082279.shtml (accessed on 25 March, 2020)

24. Zhang YZ, Holmes EC. A Genomic Perspective on the Origin and Emergence of SARS-CoV-2. Cell. 2020 Mar 26.

25. Li X, Zai J, Zhao Q, Nie Q, Li Y, Foley BT, Chaillon A. Evolutionary history, potential intermediate animal host, and cross-species analyses of SARS-CoV-2. Journal of Medical Virology. 2020 Feb 27.

26. Ren W, Li W, Yu M, Hao P, Zhang Y, Zhou P, et al. Full-length genome sequences of two SARS-like coronaviruses in horseshoe bats and genetic variation analysis. Journal of General Virology. 2006;87(11):3355-9.

27. Li W, Shi Z, Yu M, Ren W, Smith C, Epstein JH, et al. Bats are natural reservoirs of SARS-like coronaviruses. Science. 2005;310(5748):676-9.

28. Lau SK, Woo PC, Li KS, Huang Y, Tsoi HW, Wong BH, et al. Severe acute respiratory syndrome coronavirus-like virus in Chinese horseshoe bats. Proceedings of the National Academy of Sciences. 2005;102(39): 14040-5.

29. Nowotny N, Kolodziejek J. Middle East respiratory syndrome coronavirus (MERS-CoV) in dromedary camels, Oman, 2013. Eurosurveillance. 2014;19(16):20781

30. Lau SK, Zhang L, Luk HK, Xiong L, Peng X, Li KS, et al. Receptor usage of a novel bat lineage $\mathrm{c}$ beta coronavirus reveals evolution of Middle East respiratory syndrome-related coronavirus spike proteins for human dipeptidyl peptidase 4 binding. The Journal of infectious diseases. 2018;218(2):197-207.

31. Zhang Z, Shen L, Gu X. Evolutionary dynamics of MERS-CoV: potential recombination, positive selection and transmission. Scientific Reports. 2016;6(1):1-0. 
32. Enserink M. SARS: Chronology of the Epidemic. Science 2013;339:1266-71

33. Munster VJ, Koopmans M, van Doremalen N, van Riel D, de Wit E. A novel coronavirus emerging in China-key questions for impact assessment. New England Journal of Medicine. 2020;382(8):692-4. 34. Raj VS, Mou H, Smits SL, Dekkers DH, Müller MA, Dijkman R, et al. Dipeptidyl peptidase 4 is a functional receptor for the emerging human coronavirus-EMC. Nature. 2013;495(7440):251-4.

35. Wu D, Wu T, Liu Q, Yang Z. The SARS-CoV-2 outbreak: what we know. International Journal of Infectious Diseases. 2020 Mar 12 36. Ding Y, He L, Zhang Q, Huang Z, Che X, Hou J, et al. Organ distribution of severe acute respiratory syndrome (SARS) associated coronavirus (SARS-CoV) in SARS patients: implications for pathogenesis and virus transmission pathways. The Journal of Pathology 2004;203(2):622-30

37. Killerby ME, Biggs HM, Midgley CM, Gerber SI, Watson JT. Middle East respiratory syndrome coronavirus transmission. Emerging infectious diseases. 2020;26(2):191

38. WHO. Natural ventilation for infection control in health-care settings. 2009

https://www.who.int/water_sanitation health/publications/natural venti lation.pdf (accessed on 22 March 2020)

39. Kim SW, Park JW, Jung HD, Yang JS, Park YS, Lee C, et al. Risk factors for transmission of Middle East respiratory syndrome coronavirus infection during the 2015 outbreak in South Korea. Clinical Infectious Diseases. 2017;64(5):551-7

40. Oboho IK, Tomczyk SM, Al-Asmari AM, Banjar AA, Al-Mugti H, Aloraini MS, et al. 2014 MERS-CoV outbreak in Jeddah-a link to health care facilities. New England Journal of Medicine. 2015;372(9):846-54.

41. Alanazi KH, Killerby ME, Biggs HM, Abedi GR, Jokhdar H, Alsharef AA, et al. Scope and extent of healthcare-associated Middle East respiratory syndrome coronavirus transmission during two contemporaneous outbreaks in Riyadh, Saudi Arabia, 2017. Infection Control \& Hospital Epidemiology. 2019;40(1):79-88.

42. Lee N, Hui D, Wu A, Chan P, Cameron P, Joynt GM, et al. A major outbreak of severe acute respiratory syndrome in Hong Kong. New England Journal of Medicine. 2003;348(20):1986-94

43. Arita I, Kojima K, Nakane M. Transmission of severe acute respiratory syndrome. Emerging infectious diseases. 2003 Sep;9(9):1183.

44. WHO. Consensus document on the epidemiology of severe acute respiratory syndrome (SARS),2003. https://www.who.int/csr/sars/en/WHOconsensus.pdf(accessed on 22 March 2020)

45. Poissy J, Goffard A, Parmentier-Decrucq E, Favory R, Kauv M, Kipnis E, et al. Kinetics and pattern of viral excretion in biological specimens of two MERS-CoV cases. Journal of Clinical Virology. 2014;61(2):275-8.

46. Bin SY, Heo JY, Song MS, Lee J, Kim EH, Park SJ, et al. Environmental contamination and viral shedding in MERS patients during MERS-CoV outbreak in South Korea. Clinical Infectious Diseases. 2016;62(6):755-60.

47. Chan KH, Poon LL, Cheng VC, Guan Y, Hung IF, Kong J, et al. Detection of SARS coronavirus in patients with suspected SARS. Emerging infectious diseases. 2004;10(2):294

48. Guang ZE, Shu-Yun XI, Qin LI, Jian-Ming OU. Infectivity of severe acute respiratory syndrome during its incubation period. Biomedical and Environmental Sciences. 2009;22(6):502-10.

49. Chan JF, Yuan S, Kok KH, To KK, Chu H, Yang J, et al. A familial cluster of pneumonia associated with the 2019 novel coronavirus indicating person-to-person transmission: a study of a family cluster. The Lancet. 2020;395(10223):514-23

50. Liu J, Liao X, Qian S, Yuan J, Wang F, Liu Y, et al. Community Transmission of Severe Acute Respiratory Syndrome Coronavirus 2, Shenzhen, China, 2020. Emerging Infectious Diseases. 2020;26(6)

51. Li Q, Guan X, Wu P, Wang X, Zhou L, Tong Y, et al. Early transmission dynamics in Wuhan, China, of novel coronavirus-infected pneumonia. New England Journal of Medicine. 2020 Jan 29.

52. Huang C, Wang Y, Li X, Ren L, Zhao J, Hu Y, et al. Clinical features of patients infected with 2019 novel coronavirus in Wuhan, China. The Lancet. 2020;395(10223):497-506.

53. Phelan AL, Katz R, Gostin LO. The novel coronavirus originating in Wuhan, China: challenges for global health governance. JAMA. 2020;323(8):709-10.

54. WHO. How does COVID-19 Spread? Available at: https://www.who.int/news-room/q-a-detail/q-a-coronaviruses. (accessed on 22 March 2020)
55. Rothe C, Schunk M, Sothmann P, Bretzel G, Froeschl G, Wallrauch C, et al. Transmission of 2019-nCoV infection from an asymptomatic contact in Germany. New England Journal of Medicine. 2020 Jan 30.

56. Bai Y, Yao L, Wei T, Tian F, Jin DY, Chen L, Wang M. Presumed asymptomatic carrier transmission of COVID-19. Jama. 2020 Feb 21.

57. Li P, Fu JB, Li KF, Chen Y, Wang HL, Liu LJ, et al. Transmission of COVID-19 in the terminal stage of incubation period: a familial cluster. International Journal of Infectious Diseases. 2020 Mar 16. 58. WHO. Report of the WHO-China Joint Mission on Coronavirus Disease 2019 (COVID19). Geneva: WHO; 2020. Available from: https://www.who.int/docs/default-source/coronaviruse/who-china-jointmission-on-covid-19-final-report.pdf (accessed on 22 March 2020)

59. Young BE, Ong SW, Kalimuddin S, Low JG, Tan SY, Loh J, et al. Epidemiologic features and clinical course of patients infected with SARS-CoV-2 in Singapore. Jama. 2020 Mar 3.

60. Chang D, Mo G, Yuan X, Tao Y, Peng X, Wang F, et al. Time Kinetics of Viral Clearance and Resolution of Symptoms in Novel Coronavirus Infection. American Journal of Respiratory and Critical Care Medicine. 2020 Mar 23(ja).

61. Tellier R, Li Y, Cowling BJ, Tang JW. Recognition of aerosol transmission of infectious agents: a commentary. BMC Infectious Diseases. 2019;19(1):101

62. Booth TF, Kournikakis B, Bastien N, Ho J, Kobasa D, Stadnyk L, et al. Detection of airborne severe acute respiratory syndrome (SARS) coronavirus and environmental contamination in SARS outbreak units. The Journal of infectious diseases. 2005;191(9):1472-7.

63. Van Doremalen N, Bushmaker T, Munster VJ. Stability of Middle East respiratory syndrome coronavirus (MERS-CoV) under different environmental conditions. Eurosurveillance. 2013;18(38):20590

64. van Doremalen N, Bushmaker T, Morris DH, Holbrook MG, Gamble A, Williamson BN, et al. Aerosol and surface stability of SARS-CoV-2 as compared with SARS-CoV-1. New England Journal of Medicine. 2020 Mar 17.

65. WHO. Modes of transmission of virus casusing COVID-19: 29 march 2020 implications for ipc precaution recommendation. https://www.who.int/news-room/commentaries/detail/modes-oftransmission-of-virus-causing-covid-19-implications-for-ipcprecaution-recommendations(accessed on 22 March 2020)

66. Tang JW. The effect of environmental parameters on the survival of airborne infectious agents. Journal of the Royal Society Interface. 2009;6(suppl_6):S737-46.

67. Ong SW, Tan YK, Chia PY, Lee TH, Ng OT, Wong MS, et al. Air, surface environmental, and personal protective equipment contamination by severe acute respiratory syndrome coronavirus 2 (SARS-CoV-2) from a symptomatic patient. JAMA. 2020 Mar 4.

68. Bin SY, Heo JY, Song MS, Lee J, Kim EH, Park SJ, et al. Environmental contamination and viral shedding in MERS patients during MERS-CoV outbreak in South Korea. Clinical Infectious Diseases. 2016;62(6):755-60.

69. Xiao S, Li Y, Wong TW, Hui DS. Role of fomites in SARS transmission during the largest hospital outbreak in Hong Kong. PloS one. 2017;12(7).

70. Otter JA, Donskey C, Yezli S, Douthwaite S, Goldenberg SD, Weber DJ. Transmission of SARS and MERS coronaviruses and influenza virus in healthcare settings: the possible role of dry surface contamination. Journal of Hospital Infection. 2016;92(3):235-50

71. Chan KH, Peiris JS, Lam SY, Poon LL, Yuen KY, Seto WH. The effects of temperature and relative humidity on the viability of the SARS coronavirus. Advances in Virology 2011;2011

72. Duan SM, Zhao XS, Wen RF, Huang JJ, Pi GH, Zhang SX, et al. Stability of SARS coronavirus in human specimens and environment and its sensitivity to heating and UV irradiation. Biomedical and environmental sciences: BES. 2003;16(3):246-55.

73. Rabenau HF, Cinatl J, Morgenstern B, Bauer G, Preiser W, Doerr HW. Stability and inactivation of SARS coronavirus. Medical microbiology and immunology. 2005;194(1-2):1-6.

74. Lai MY, Cheng PK, Lim WW. Survival of severe acute respiratory syndrome coronavirus. Clinical Infectious Diseases. 2005;41(7):e6771 .

75. HUFFPOST. How long coronaviruses live on cloths and how to wash them https://www.huffpost.com/entry/how-long-coronavirus-live clothingwashing 1 5e724927c5b6eab779409e 74? fbclid=IwAR2nn Kv TPSnmHQdFuZkqUwb4GTpWmw0BEcWij6THsA UX0-jlrervblrJc (accessed on 23 March 2020)

76. Mirror. Why you should leave your shoes outside your house during coronavirus pandemic https://www.mirror.co.uk/news/uk- 
news/you-should-leave-your-shoes-21760757 (accessed on 23 March 2020)

77. WHO. Consensus document on the epidemiology of SARS. Weekly Epidemiological Record 2003;78(43):373-5.

78. Assiri A, Al-Tawfiq JA, Al-Rabeeah AA, Al-Rabiah FA, Al-Hajjar S, Al-Barrak A, et al. Epidemiological, demographic, and clinical characteristics of 47 cases of Middle East respiratory syndrome coronavirus disease from Saudi Arabia: a descriptive study. The Lancet infectious diseases. 2013;13(9):752-61

79. Corman VM, Albarrak AM, Omrani AS, Albarrak MM, Farah ME, Almasri M, et al. Viral shedding and antibody response in 37 patients with Middle East respiratory syndrome coronavirus infection. Clinical Infectious Diseases. 2016;62(4):477-83.

80. Xing Y, Ni W, Wu Q, Li W, Li G, Tong J, et al. Prolonged presence of SARS-CoV-2 in feces of pediatric patients during the convalescent phase. medRxiv. 2020 Jan 1.

81. Holshue ML, DeBolt C, Lindquist S, Lofy KH, Wiesman J, Bruce $\mathrm{H}$, et al. First case of 2019 novel coronavirus in the United States. New England Journal of Medicine. 2020 Jan 31

82. Wu Y, Guo C, Tang L, Hong Z, Zhou J, Dong X, et al. Prolonged presence of SARS-CoV-2 viral RNA in faecal samples. The Lancet Gastroenterology \& Hepatology. 2020 Mar 20.

83. Wang W, Xu Y, Gao R, Lu R, Han K, Wu G, et al. Detection of SARS-CoV-2 in different types of clinical specimens. JAMA. 2020 Mar 11

84. Zhang Y, Chen C, Zhu S, Shu C, Wang D, Song J, et al. Isolation of 2019-nCoV from a stool specimen of a laboratory-confirmed case of the coronavirus disease 2019 (COVID-19). China CDC Weekly. 2020;2(8):123-4.

85. Xu H, Zhong L, Deng J, Peng J, Dan H, Zeng X, et al. High expression of ACE2 receptor of 2019-nCoV on the epithelial cells of oral mucosa. International Journal of Oral Science. 2020;12(1):1-5. 86. Wong SF, Chow KM, Leung TN, Ng WF, Ng TK, Shek CC, et al. Pregnancy and perinatal outcomes of women with severe acute respiratory syndrome. American journal of obstetrics and gynecology. 2004:191(1):292-7.

87. Alserehi H, Wali G, Alshukairi A, Alraddadi B. Impact of Middle East Respiratory Syndrome coronavirus (MERS-CoV) on pregnancy and perinatal outcome. BMC infectious diseases. 2016;16(1):105.

88. Creanga AA, Johnson TF, Graitcer SB, Hartman LK, Al-Samarrai T, Schwarz AG, et al. Severity of 2009 pandemic influenza A (H1N1) virus infection in pregnant women. Obstetrics \& Gynecology. 2010;115(4):717-26

89. Silasi M, Cardenas I, Kwon JY, Racicot K, Aldo P, Mor G. Viral infections during pregnancy. American Journal of Reproductive Immunology. 2015;73(3):199-213

90. Lam CM, Wong SF, Leung TN, Chow KM, Yu WC, Wong TY, Lai ST, Ho LC. A case-controlled study comparing clinical course and outcomes of pregnant and non-pregnant women with severe acute respiratory syndrome. BJOG: An International Journal of Obstetrics \& Gynaecology. 2004;111(8):771-4

91. Assiri A, Abedi GR, Al Masri M, Bin Saeed A, Gerber SI, Watson JT. Middle East Respiratory Syndrome Coronavirus infection during pregnancy: a report of 5 cases from Saudi Arabia. Clinical Infectious Diseases. 2016;63(7):951-3

92. Shek CC, Ng PC, Fung GP, Cheng FW, Chan PK, Peiris MJ, et al. Infants born to mothers with severe acute respiratory syndrome. Pediatrics. 2003;112(4):e254

93. Wang X, Zhou Z, Zhang J, Zhu F, Tang Y, Shen X, et al. A case of 2019 Novel Coronavirus in a pregnant woman with preterm delivery.

94. Zhu H, Wang L, Fang C, Peng S, Zhang L, Chang G, et al. Clinical analysis of 10 neonates born to mothers with 2019-nCoV pneumonia. Translational Pediatrics. 2020;9(1):51
95. Fan C, Lei D, Fang C, Li C, Wang M, Liu Y, et al. Perinatal Transmission of COVID-19 Associated SARS-CoV-2: Should We Worry? Clinical Infectious Diseases. 2020 Mar 17

96. Chen H, Guo J, Wang C, Luo F, Yu X, Zhang W, et al. Clinical characteristics and intrauterine vertical transmission potential of COVID-19 infection in nine pregnant women: a retrospective review of medical records. The Lancet. 2020;395(10226):809-15

97. CCTV.COM. A 30-hour old infant in Wuhan diagnosed and mother-to-child infection suspected. Available at: http://m.news.cctv.com/2020/02/05/ARTIywVxQICUUURSIWzSz vkf200205.shtml (accessed on 23 March 2020)

98. Technology, T.H.T.M.C.H.U.o.S.a. Be Alert to the Risk of Motherto-Child vertical Transmission

And the First New Coronavirus infection of a Newborn Was Diagnosed in Tongji Hospital, ChuTian Metropolis Daily, 2020, p. 2020.

99. Drosten C, Günther S, Preiser W, Van Der Werf S, Brodt HR, Becker S, et al. Identification of a novel coronavirus in patients with severe acute respiratory syndrome. New England Journal of Medicine. 2003:348(20):1967-76

100. Grant PR, Garson JA, Tedder RS, Chan PK, Tam JS, Sung JJ. Detection of SARS coronavirus in plasma by real-time RT-PCR. New Engl J Med. 2003;349(25):2468-9.

101. Ng EK, Hui DS, Chan KA, Hung EC, Chiu RW, Lee N, et al. Quantitative analysis and prognostic implication of SARS coronavirus RNA in the plasma and serum of patients with severe acute respiratory syndrome. Clinical Chemistry. 2003:49(12):1976-80

102. Ng EK, Ng PC, Hon KE, Cheng WF, Hung EC, Chan KA, et al. Serial analysis of the plasma concentration of SARS coronavirus RNA in pediatric patients with severe acute respiratory syndrome. Clinical Chemistry. 2003;49(12):2085-8.

103. Shang G, Biggerstaff BJ, Yang B, Shao C, Farrugia A. Theoretically estimated risk of severe acute respiratory syndrome transmission through blood transfusion during an epidemic in Shenzhen, Guangdong, China in 2003. Transfusion and Apheresis Science. 2007;37(3):233-40.

104. Chafekar A, Fielding BC. MERS-CoV: understanding the latest human coronavirus threat. Viruses. $2018 \mathrm{Feb} ; 10(2): 93$.

105. Huang C, Wang Y, Li X, Ren L, Zhao J, Hu Y, et al. Clinical features of patients infected with 2019 novel coronavirus in Wuhan, China. The Lancet. 2020;395(10223):497-506

106. World Health Organization. WHO recommendations on SARS and blood safety. Website: http://www.who.int/csr/sars/guidelines/bloodsafety/en/; 2003 (accessed on 25 March 2020)

107. Chan JF, Yuan S, Kok KH, To KK, Chu H, Yang J, et al. A familial cluster of pneumonia associated with the 2019 novel coronavirus indicating person-to-person transmission: a study of a family cluster. The Lancet. 2020;395(10223):514-23

108. Shen K, Yang Y, Wang T, Zhao D, Jiang Y, Jin R, et al. Diagnosis, treatment, and prevention of 2019 novel coronavirus infection in children: experts' consensus statement. World Journal of Pediatrics. 2020:1-9

109. Xia J, Tong J, Liu M, Shen Y, Guo D. Evaluation of coronavirus in tears and conjunctiva secretions of patients with SARS-CoV-2 infection. J Med Virol. 2020 Feb 26

110. Sun X, Zhang X, Chen X, Chen L, Deng C, Zou X, et al. The infection evidence of SARS-COV-2 in ocular surface: a single-center cross-sectional study. medRxiv. $2020 \mathrm{Feb} 26$

111. Xu L, Zhang X, Song W, Sun B, Mu J, Dong X, et al. Conjunctiva polymerase chain reaction-tests of 2019 novel coronavirus in patients in Shenyang, China. medRxiv. 2020 Feb 23 